\title{
PENGARUH PENAMBAHAN TEPUNG SUKUN (ARTOCARPUS COMMUNIS), PISANG HIJAU (MUSA PARADISIACA L.), COKELAT (THEOBROMA CACAO L.) DAN KURMA (PHOENIX DACTYLIFERA) TERHADAP DAYA TERIMA DAN NILAI KARBOHIDRAT EGG ROLL
}

\author{
The Effect of Breadfruit Flour (Artocarpus Communis), Green Bananas (Musa Paradisiaca \\ L.), Chocolate (Theobroma Cacao L.) and Dates (Phoenix Dactylifera) Addition Toward the \\ Acceptance and Carbohydrate Content of Egg Roll
}

\author{
Kholifatul Hafidha ${ }^{1}$, Rita Ismawati ${ }^{2}$ \\ ${ }^{1}$ Program Studi Ilmu Gizi, Fakultas Kesehatan Masyarakat, Universitas Airlangga, Surabaya \\ ${ }^{2}$ Prodi Gizi, Jurusan PKK, Fakultas Teknik, Universitas Negeri Surabaya \\ E-mail: kholifatul.hafidha@gmail.com
}

\begin{abstract}
ABSTRAK
Karbohidrat memiliki peranan penting bagi atlet endurance untuk mengisi kembali simpanan glikogen otot dan hati yang telah habis terpakai pada saat kontraksi otot (olahraga). Penelitian ini bertujuan untuk menganalisa pengaruh penambahan tepung sukun (Artocarpus communis), pisang hijau (Musa paradisiaca L.), kurma (Phoenix dactylifera) dan cokelat (Theobroma cacao L.) terhadap daya terima dan kandungan karbohidrat egg roll sebagai alternatif snack pada atlet endurance. Penelitian ini menggunakan desain penelitian eksperimental murni dengan Rancangan Acak Lengkap (RAL) sebanyak 4 perlakuan dengan masing-masing 4 kali pengulangan. Panelis pada penelitian ini berjumlah 30 atlet Puslatda KONI Jawa Timur. Berdasarkan hasil uji daya terima formula egg roll modifikasi yang paling disukai adalah F1 (tepung sukun $150 \mathrm{~g}$, cokelat $500 \mathrm{~g}$ dan kurma $150 \mathrm{~g}$ ) dengan nilai mean rank tertinggi pada karakteristik warna $(2,65)$ dan rasa $(2,70)$, sedangkan pada penilaian aroma dan tekstur nilai mean rank lebih rendah (masing-masing 2,50) dibanding F0 (2,87 dan 2,58). Hasil uji statistik Friedman Test terhadap seluruh karakteristik daya terima meliputi warna, aroma, tekstur dan rasa diketahui bahwa tidak terdapat perbedaan yang signifikan terhadap daya terima egg roll ( $\mathrm{p}>0,05)$. Formula dengan kadar karbohidrat tertinggi dimiliki oleh F1 yaitu sebesar 59,4/100 g egg roll. Berdasarkan nilai daya terima terbaik dan kandungan karbohidrat tertinggi, maka disimpulkan bahwa formula optimasi pada penelitian ini adalah F1. Jumlah egg roll yang sebaiknya dikonsumsi atlet pada saat sebelum olahraga adalah 125 gram (12 batang egg roll) dan 60-95 gram (6-8 batang egg roll) untuk setelah olahraga.
\end{abstract}

Kata kunci: atlet endurance, cokelat, egg roll, pisang hijau, kurma, tepung sukun

\begin{abstract}
Carbohydrates have an important role for endurance athletes to replenish glycogen in muscle and liver that had been used during muscle contraction. This research aims to analyze the effect of adding breadfruit flour (Artocarpus communis), green banana (Musa paradisiaca L.), dates (Phoenix dactylifera) and chocolate (Theobroma cacao L.) toward the acceptance and carbohydrate content of egg roll as an alternative snack for endurance athletes. This research use True Experimental Research, completely randomized design with four formula and repeated four times for each formula. Panelist in this study consist of 30 athletes of Local Training Center, Indonesian National Sport Committee in East Java Region. Based on the test of acceptance on the modification of egg roll formula, the most preferred formula was $F 1$ (breadfruit flour $150 \mathrm{~g}$, chocolate $500 \mathrm{~g}$, dates $150 \mathrm{~g}$ ) with the highest mean rank values were on color (2.65) and flavor (2.70), while the aroma and texture aspect had the lower mean rank (2.50) each compared to F0 (2.87 and 2.58). The result of Friedman Test statistic on all characteristics of the acceptability include color, aroma, texture and flavor found there was not significant difference on the acceptance of egg roll ( $p>0.05)$. The highest carbohydrate content was F1 (59.4/100 g). Based on the best acceptance value and the highest carbohydrate content, it was conclude that the optimal formula was F1. Total egg roll that should be consumed by the athletes before sport was 125 grams (12 sticks egg roll) and 60-95 grams (6-8 sticks egg roll) for after sport.
\end{abstract}

Keywords: endurance athlete, chocolate, egg roll, green banana, dates, breadfruit flour

Kholifatul Hafidha, et al., MGI(2018) 81-88

DOI: 10.20473/mgi.v13i1.81-88. 


\section{PENDAHULUAN}

Pembangunan prestasi olahraga merupakan suatu proses saling terkait yang tidak hanya dipengaruhi oleh kekuatan fisik saja, namun juga diperlukan dukungan dari berbagai disiplin keilmuan, salah satunya adalah gizi (Kemenkes RI, 2014). Berdasarkan penelitian Mustamin, et al. (2010) diketahui bahwa 40\% atlet memiliki asupan energi yang relatif kurang. Penelitian lebih lanjut yang dilakukan oleh Dietetians of Canada (2016) bahwa tiga dari enam studi yang dilakukan di Kanada menunjukkan bahwa ketidakseimbangan antara jumlah asupan dan keluaran energi pada atlet berdampak pada penurunan kualitas performa di lapangan. Olahraga endurance merupakan jenis olahraga yang mengutamakan kekuatan daya tahan dan dilakukan dalam durasi yang cukup lama (>90 menit), sehingga rawan untuk mengalami kekurangan energi. Salah satu upaya yang dapat dilakukan guna mendukung peningkatan prestasi olahraga adalah melalui upaya perbaikan gizi para pelaku olahraga (atlet) (Kemenkes RI, 2014).

Kegiatan olahraga yang dilakukan secara terus menerus menyebabkan terjadinya penurunan simpanan glikogen didalam otot dan hati yang telah terkuras habis pada saat pertandingan. Glukosa pada aliran darah akan menjadi sumber energi utama pada awal pergerakan atlet, selanjutnya tubuh akan menggunakan simpanan glikogen dalam otot dan hati. Glikogen otot dapat langsung diubah menjadi energi, namun simpanan glikogen pada hati akan mengalami perubahan terlebih dahulu untuk kemudian dapat digunakan oleh otot (Kemenkes, 2014). Oleh karena itu, salah satu jenis zat gizi yang sebaiknya diberikan pada fase ini adalah makanan sumber karbohidrat dengan nilai indeks glikemik tinggi dalam porsi kecil (snack) (Universitas Esa Unggul, 2014).

Menurut Driskell, et al. (2011) pemilihan jenis dan jumlah snack yang tepat akan berdampak positif terhadap peningkatan performa atlet. Namun, ketersediaan snack khusus bagi atlet masih jarang ditemukan di pasaran khususnya untuk produk berbasis pangan lokal. Oleh karena itu, pengembangan produk snack yang sesuai, dengan memanfaatkan potensi pangan lokal perlu untuk dilakukan sebagai upaya mendukung kegiatan diversifikasi pangan lokal (Kementerian Perdagangan RI, 2013).

Buah sukun (Artocarpus communis) dan pisang hijau (Musa paradisiaca L.) memiliki kandungan karbohidrat yang tinggi sehingga berpotensi sebagai makanan sumber energi bagi atlet endurance. Pengolahan buah sukun dan pisang menjadi tepung, berturut-turut mengandung karbohidrat sebesar $78,9 \mathrm{~g}$ dan $88,6 \mathrm{~g}$ per $100 \mathrm{~g}$ masing-masing bahan (Hendri, et al., 2010). Berdasarkan statistik produksi (2015), pisang merupakan persentase produksi tertinggi untuk kategori buah yaitu 6.862 .558 ton $(34,65 \%)$, sedangkan produksi buah sukun sepanjang tahun 2009-2014 sebesar 104.071 ton. Disisi lain cokelat (Theobroma cacao L.) dan kurma (Phoenix dactylifera) merupakan dua tanaman yang sedang dikembangkan produksinya di Indonesia. Berdasarkan data BPS, rata-rata produksi tanaman cokelat di Indonesia sepanjang tahun 2006-2013 sebanyak 834,125 kg/ha (Kementerian Pertanian, 2014). Pada $100 \mathrm{~g}$ buah kurma mampu menyediakan energi sebesar 314 kkal dengan komposisi utama berupa monosakarida (Dayang, et al., 2014).

Salah satu upaya pengembangan produk snack yang dapat dilakukan adalah egg roll. Egg roll merupakan jenis kue kering yang memiliki rasa manis, tekstur renyah, berbentuk gulungan utuh berlubang serta mudah rapuh (Fadhilah, 2015). Pada umumnya, egg roll dibuat dengan bahan dasar tepung terigu dan telur serta terdapat lubang pada bagian tengahnya. Adanya lubang pada bagian tengah egg roll berpotensi untuk ditambahkan bahan lain sebagai isian untuk meningkatkan nilai gizi egg roll.

Dengan demikian, berdasarkan uraian diatas, diperlukan pengembangan produk egg roll serta mengetahui pengaruh penambahan tepung sukun, pisang hijau, kurma dan cokelat terhadap daya terima serta nilai karbohidrat yang tepat sehingga dapat dijadikan sebagai salah satu referensi pemilihan snack untuk mendukung kebutuhan gizi pada atlet endurance. 


\section{METODE}

Penelitian ini terdiri atas dua tahap, yaitu tahap pengembangan produk dan tahap uji daya terima kepada panelis. Desain penelitian pada tahap pengembangan produk formulasi adalah eksperimental murni (True Experimental Research) dengan rancang bangun penelitian Rancang Acak Lengkap (RAL), dimana pada formula egg roll ditambahkan tepung sukun, pisang hijau, kurma dan cokelat dengan 4 macam formula. Penelitian ini dilakukan selama 5 bulan yaitu pada bulan Februari hingga Juli 2017. Tahap penelitian pengembangan produk egg roll dilakukan di Laboratorium Gizi Fakultas Kesehatan Masyarakat Universitas Airlangga Surabaya dan UKM Ngudi Roso Cepu. Penelitian terhadap daya terima panelis tidak terlatih dilakukan di Komite Olahraga Nasional Indonesia (KONI) Jawa Timur dan untuk uji nilai gizi pada formula terbaik dilakukan di Laboratorium Gizi Universitas Airlangga Surabaya.

Sampel yang digunakan untuk mengetahui kandungan nilai energi dan karbohidrat pada produk sebesar 100 gram pada masing-masing formula, sedangkan untuk mengetahui daya terima panelis, maka sampel yang disajikan sebesar $30 \mathrm{~g}$ egg roll pada setiap formula terpilih. Metode pengambilan sampel dilakukan secara random sehingga seluruh sampel yang disajikan memiliki peluang yang sama untuk diberikan perlakuan.

Panelis yang terlibat dalam penelitian ini merupakan atlet Puslatda KONI Jawa Timur

Tabel 1. Formulasi Egg Roll Dasar dan Egg Roll Modifikasi

\begin{tabular}{lcccc}
\hline \multirow{2}{*}{ Komposisi } & \multicolumn{4}{c}{ Formula (g) } \\
\cline { 2 - 5 } & F0 & F1 & F2 & F3 \\
\hline Adonan Egg Roll & & & & \\
Tepung Terigu & 500 & 500 & 500 & 500 \\
Tepung Sukun & 0 & 150 & 0 & 150 \\
Pisang Hijau & 0 & 0 & 500 & 350 \\
Telur Ayam & 320 & 320 & 320 & 320 \\
Mentega & 200 & 200 & 200 & 200 \\
Gula Pasir & 400 & 400 & 400 & 400 \\
Santan & 400 & 400 & 400 & 400 \\
Susu bubuk & 50 & 50 & 50 & 50 \\
Isian Egg Roll & & & & \\
Cokelat & 0 & 500 & 500 & 500 \\
Kurma & 0 & 150 & 125 & 50 \\
\hline
\end{tabular}

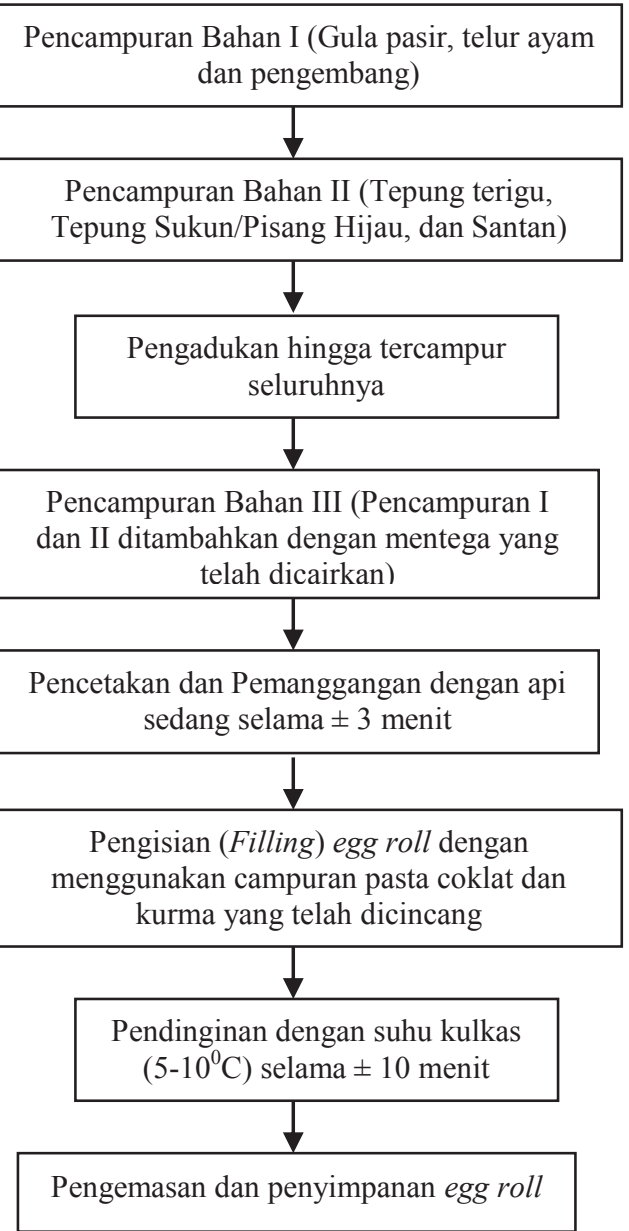

Gambar 1. Diagram Alir Pembuatan Egg Roll

berjumlah 30 orang yang kemudian diminta untuk menilai beberapa formula egg roll yang disajikan meliputi daya terima warna, aroma, tekstur dan rasa menggunakan angket uji kesukaan (hedonic scale test) yaitu suka, agak suka, dan tidak suka.

Tahapan pengolahan egg roll dengan penambahan tepung sukun, pisang hijau, kurma dan cokelat disajikan pada gambar diagram alir 1 .

Bahan yang digunakan dalam pengembangan produk egg roll modifikasi ini terdiri dari tepung terigu, tepung sukun, pisang hijau, telur ayam, mentega, gula pasir, santan, susu bubuk, cokelat dan kurma sebagaimana yang disajikan pada tabel 1 .

Teknik pengumpulan data pada penelitian ini dilakukan melalui penilaian daya terima panelis terhadap karakteristik warna, aroma, tekstur dan rasa menggunakan angket uji kesukaan dan melakukan perhitungan nilai karbohidrat 
berdasarkan Tabel Komposisi Pangan Indonesia (TKPI).

Setelah dilakukan uji kesukaan panelis dari seluruh formula egg roll, data hasil penilaian tersebut diolah untuk menemukan formula dengan tingkat kesukaan tertinggi, selanjutnya dilakukan uji analisis proximate untuk mengetahui kadar energi dan karbohidrat. Teknik analisis data secara statistik pada penilaian daya terima egg roll dilakukan dengan menggunakan uji Friedman Test. Penelitian ini melibatkan manusia sebagai panelis. Penelitian ini telah memperoleh persetujuan komisi etik penelitian kesehatan No: 224-KEPK Fakultas Kesehatan Masyarakat Universitas Airlangga Surabaya. Untuk mengetahui respons daya terima produk egg roll.

\section{HASIL DAN PEMBAHASAN}

\section{Daya Terima Egg Roll}

Uji daya terima kepada 30 orang panelis tidak terlatih (atlet) dilakukan untuk mengetahui tingkat kesukaan panelis terhadap karakteristik warna, aroma, tekstur dan rasa egg roll. Adanya perbedaan jumlah tepung sukun, pisang hijau kurma dan cokelat pada masing-masing formula akan memberikan karakteristik egg roll yang berbeda. Hasil uji kesukaan panelis terhadap karakteristik warna, aroma, tekstur dan rasa egg roll dapat dilihat pada tabel 2.

Pada tabel 2 diketahui nilai mean rank tertinggi dari 4 formula yang disajikan kepada panelis tidak terlatih adalah F1 $(2,65)$. Namun, persentase kesukaan panelis terhadap formula F1 sama dengan F3 yaitu 66,67\%. Formula egg roll F1 memiliki warna kuning agak kusam. Timbulnya warna kusam pada egg roll diakibatkan adanya penambahan tepung sukun pada adonan egg roll. Buah sukun merupakan salah satu jenis buah yang mudah mengalami pencokelatan, hal ini dikarenakan adanya reaksi antara oksigen dengan senyawa phenol yang dikatalis oleh polyphenol oksidase sehingga mengaktifkan enzim pada buah sukun (browning enzymatic) (Widowati, et al., 2001). Reaksi tersebut dapat terjadi pada saat proses penepungan, dimana terjadi kontak antara udara bebas dengan daging buah sukun. Guna meminimalisir terjadinya pencokelatan maka dapat dilakukan perendam daging buah sukun dengan larutan garam atau Natrium Pyrophospat untuk menginaktifkan enzim (Edahwati, et al., 2010). Namun demikian, tepung sukun yang digunakan pada penelitian merupakan tepung sukun siap pakai (tidak dilakukan penepungan sendiri) dengan kualitas terbaik. Hal tersebut dilakukan untuk menekan pengeluaran biaya dan waktu sehingga proses penelitian menjadi lebih efektif. Reaksi pencokelatan pada egg roll juga dapat disebabkan terjadinya reaksi antara gula pereduksi pada bahan dengan protein pada telur yang disebut sebagai reaksi mailard (Winarno, 2004).

Standar aroma egg roll pada formula kontrol F0 adalah aroma khas telur (Adlee dalam Pradewi, 2013). Penambahan tepung sukun, pisang hijau, kurma dan cokelat pada 3 formula egg roll modifikasi memberikan aroma yang berbeda. Hasil uji kesukaan kepada 30 panelis tidak terlatih terhadap karakteristik aroma egg roll disajikan pada tabel 2. Pada tabel 2 diketahui bahwa sebanyak $60 \%$ dari 30 panelis tidak terlatih (atlet) lebih menyukai aroma egg roll kontrol dibandingkan dengan egg roll modifikasi. Ketidakbiasaan panelis dalam mengonsumsi bahan komponen penyusun seperti tepung sukun dan pisang hijau menjadi salah satu faktor rendahnya penerimaan panelis terhadap karakteristik aroma. Hal tersebut didukung oleh penelitian yang dilakukan Sukandar, et al. (2014) bahwasanya penambahan tepung sukun pada produk makanan dapat menurunkan penerimaan konsumen terhadap produk tersebut. Selain itu aroma tepung sukun dan pisang hijau tidak dapat hilang melalui proses pengolahan (Widowati, et al., 2001).

Pada umumnya egg roll memiliki tekstur yang renyah namun mudah rapuh (Adlee dalam Pradewi, 2013). Hasil uji daya terima panelis tidak terlatih (atlet) terhadap karakteristik tekstur terhadap formula egg roll didapatkan nilai mean rank kesukaan panelis pada formula F1 $(2,52)$ lebih tinggi dibandingkan dengan formula modifikasi lainnya, namun masih lebih rendah dibandingkan dengan F0 (2,58). Pada formula F0 tekstur egg roll lebih mudah rapuh, sedangkan pada F1 lebih padat dan renyah. Tingkat kerapuhan pada formula egg roll disebabkan oleh penggunaan telur dalam jumlah yang cukup banyak. Kandungan asam 
lemak yang tinggi pada telur mampu meminimalisi tingkat kekerasan pada suatu makanan sehingga menjadikan tekstur makanan menjadi lebih lembut (Tan, et al., 2012). Penambahan tepung sukun dan pisang hijau pada adonan egg roll juga dapat meningkatkan kandungan amilosa sehingga adonan egg roll menjadi lebih padat dibandingkan formula dasar. Semakin tinggi kandungan amilosa pada suatu bahan makanan, maka akan menyebabkan teksturnya semakin keras (Winarno, 2004). Selain itu, penambahan kurma dan cokelat sebagai filling egg roll pada formula F1 merupakan suatu inovasi produk egg roll dengan tekstur yang lebih padat dan tidak mudah hancur sehingga sesuai untuk dijadikan sebagai salah satu snack bagi atlet endurance.

Rasa merupakan salah satu aspek penilaian daya terima yang sangat subjektif dengan mengandalkan indera perasa. Perbedaan rasa pada suatu makanan dapat diketahui oleh papila lidah melalui kuncup cecapan. Rasa menjadi faktor utama seorang konsumen akan menerima ataupun menolak suatu produk makanan (Winarno, 2004). Berdasarkan hasil uji daya terima panelis terhadap karakteristik rasa egg roll yang disajikan, distribusi nilai mean rank tertinggi adalah F1 $(2,70)$. Persentase tingkat kesukaan panelis terhadap rasa egg roll formula $\mathrm{F} 1$ (63,33\%) lebih tinggi dibandingkan dengan F0 $(2,35)$. Nilai mean rank pada formula modifikasi F2 dan F3 juga lebih tinggi dibandingkan dengan formula kontrol.

Pada umumnya produk egg roll yang beredar di pasaran memiliki rasa yang manis dan gurih (Adlee dalam Pradewi, 2013).

Penambahan tepung sukun, pisang hijau, kurma dan cokelat memberikan perpaduan rasa yang berbeda dibandingkan dengan formula kontrol. Buah sukun memiliki komponen rasa pahit seperti tanin, $\mathrm{HCN}$, dan asam fitat sehingga menimbulkan after taste yang agak pahit. Pengolahan buah sukun menjadi bentuk tepung merupakan suatu teknologi yang tepat untuk meminimalisir rasa pahit (Balitbangtan, 2015). Formula egg roll didasarkan pada penambahan jumlah dan jenis bahan seperti tepung sukun,

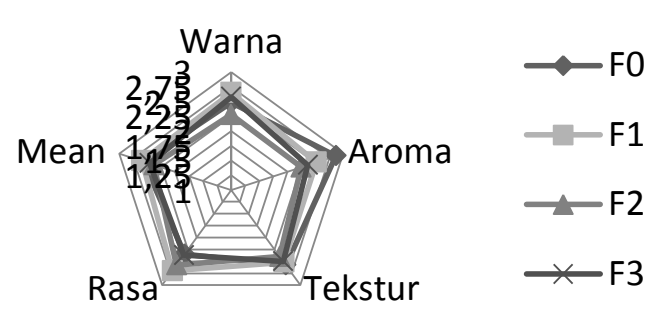

Gambar 2. Grafik Radar Tingkat Kesukaan Panelis

pisang hijau, cokelat dan kurma sehingga akan berpengaruh terhadap warna, aroma, tekstur dan rasa egg roll. Bahwa formula dengan F1 memiliki distribusi nilai mean rank tertinggi untuk karakteristik warna, tekstur dan rasa, namun rendah untuk penilaian aroma.

Daya terima egg roll untuk karakteristik aroma tertinggi dimiliki oleh formula egg roll kontrol F0. Hasil uji statistik terhadap seluruh karakteristik egg roll meliputi warna, aroma, tekstur, dan rasa diketahui bahwa tidak terdapat perbedaan yang signifikan terhadap daya terima egg roll dengan penambahan tepung sukun, pisang hijau, kurma, dan cokelat dibandingkan dengan formula egg roll kontrol.

\section{Nilai Gizi Egg Roll}

Selain aspek daya terima egg roll, penyediaan snack bagi atlet juga harus memperhatikan kebutuhan energi dan zat gizi yang paling diperlukan oleh masing-masing cabang olahraga. Olahraga endurance merupakan jenis olahraga yang dilakukan dengan intensitas rendah hingga sedang dalam kurun waktu yang cukup lama. Sebagian besar energi yang diperoleh pada cabang olahraga endurance berasal dari proses aerobik melalui pembakaran zat gizi terutama karbohidrat (Kemenkes RI, 2014) Durasi olahraga yang cukup lama menjadi pertimbangan untuk menyuplai simpanan glikogen dalam otot secara cepat sehingga performa atlet dapat dipertahankan.

Egg roll dengan penambahan tepung sukun, pisang hijau, cokelat dan kurma merupakan salah 
Tabel 2. Distribusi Tingkat Kesukaan pada Karakteristik Egg Roll

\begin{tabular}{|c|c|c|c|c|c|c|c|c|c|c|}
\hline \multirow{2}{*}{ Karakteristik } & \multicolumn{2}{|c|}{ Tidak Suka } & \multicolumn{2}{|c|}{ Agak Suka } & \multicolumn{2}{|c|}{ Suka } & \multicolumn{2}{|c|}{ Total } & \multirow{2}{*}{ Mean Rank } & \multirow{2}{*}{ p-value } \\
\hline & $\mathbf{n}$ & $\%$ & $\mathbf{n}$ & $\%$ & n & $\%$ & n & $\%$ & & \\
\hline \multicolumn{11}{|l|}{ Warna } \\
\hline F0 & 3 & 10,00 & 8 & 26,67 & 19 & 63,33 & 30 & 100 & 2,48 & \multirow{4}{*}{0,371} \\
\hline F1 & 0 & 0,00 & 10 & 33,33 & 20 & 66,67 & 30 & 100 & 2,65 & \\
\hline $\mathrm{F} 2$ & 6 & 20,00 & 8 & 26,67 & 16 & 53,33 & 30 & 100 & 2,28 & \\
\hline F3 & 4 & 13,33 & 6 & 20,00 & 20 & 66,67 & 30 & 100 & 2,58 & \\
\hline \multicolumn{11}{|l|}{ Aroma } \\
\hline F0 & 3 & 10,00 & 9 & 30,00 & 18 & 60,00 & 30 & 100 & 2,87 & \multirow{4}{*}{0,114} \\
\hline F1 & 4 & 13,33 & 13 & 43,33 & 13 & 43,33 & 30 & 100 & 2,52 & \\
\hline $\mathrm{F} 2$ & 8 & 26,67 & 11 & 36,67 & 11 & 36,67 & 30 & 100 & 2,25 & \\
\hline F3 & 7 & 23,33 & 11 & 36,67 & 12 & 36,67 & 30 & 100 & 2,37 & \\
\hline \multicolumn{11}{|l|}{ Tekstur } \\
\hline F0 & 4 & 13,33 & 7 & 23,33 & 19 & 63,33 & 30 & 100 & 2,58 & \multirow{4}{*}{0,916} \\
\hline F1 & 0 & 0,00 & 13 & 43,33 & 17 & 56,67 & 30 & 100 & 2,52 & \\
\hline $\mathrm{F} 2$ & 2 & 6,67 & 11 & 36,67 & 17 & 56,67 & 30 & 100 & 2,40 & \\
\hline F3 & 5 & 16,67 & 6 & 20,00 & 19 & 63,33 & 30 & 100 & 2,50 & \\
\hline \multicolumn{11}{|l|}{ Rasa } \\
\hline F0 & 5 & 16,67 & 10 & 33,33 & 15 & 50,00 & 30 & 100 & 2,35 & \multirow{4}{*}{0,59} \\
\hline F1 & 1 & 3,33 & 10 & 33,33 & 19 & 63,33 & 30 & 100 & 2,70 & \\
\hline F2 & 1 & 3,33 & 12 & 40,00 & 17 & 56,67 & 30 & 100 & 2,58 & \\
\hline F3 & 5 & 16,67 & 9 & 30,00 & 16 & 53,33 & 30 & 100 & 2,37 & \\
\hline
\end{tabular}

satu produk snack yang tinggi akan kandungan karbohidrat.

Pada tabel 3 disajikan hasil perhitungan Tabel Komposisi Pangan Indonesia (TKPI) untuk 100 gram produk egg roll.

Pada tabel 3 dapat diketahui bahwa kadar karbohidrat tertinggi terdapat pada formula F1 (penambahan tepung sukun $150 \mathrm{~g}$, cokelat 500 g, kurma 150 g) sedangkan untuk yang kadar terendah adalah formula F0 (tanpa perlakuan). Berdasarkan pedoman olahraga prestasi (2014), jumlah karbohidrat yang diperlukan oleh atlet endurance sebesar 60-65\%. Makanan selingan setidaknya berkontribusi $10-15 \%$ dalam memenuhi kebutuhan energi harian (Almatsier, 2004). Sehingga jumlah karbohidrat minimal pada makanan selingan (snack) bagi atlet sebesar 10-15\% (56,9 g-85,4 g). Berdasarkan hasil uji laboratorium yang dilakukan oleh pada sampel egg roll terbaik (F1), diketahui bahwa terjadi penurunan kadar karbohidrat sebanyak $8 \mathrm{~g}$, hal tersebut disebabkan adanya proses pemanggangan pada egg roll sehingga terjadi hidrolisis pada gelatinisasi pati yang menyebabkan karbohidrat terurai (Palupi, et al., 2007).

Walaupun demikian, jumlah karbohidrat pada egg roll formula terbaik (F1) masih dapat
Tabel 3. Distribusi Kadar Karbohidrat per $100 \mathrm{~g}$ Egg Roll

\begin{tabular}{ccc}
\hline \multirow{2}{*}{ Formula } & \multicolumn{2}{c}{ Kadar Karbohidrat (g) } \\
\cline { 2 - 3 } & Perhitungan TKPI & Uji Laboratorium \\
\hline F0 & 44,4 & - \\
F1 & 59,4 & 51,4 \\
F2 & 45,1 & - \\
F3 & 45,6 & - \\
\hline
\end{tabular}

-) tidak dilakukan uji laboratorium

memenuhi kebutuhan karbohidrat pada atlet sebesar 11,2\%. Kadar karbohidrat pada F0 sebesar 44,4 g dan meningkat pada F2 menjadi 59,4. Penambahan tepung sukun, kurma, dan cokelat (F1) dapat meningkatkan jumlah karbohidrat sebanyak $15 \mathrm{~g}$. Hal ini sejalan dengan penelitian yang dilakukan oleh Partogi, et al. (2012) bahwa penambahan tepung sukun pada pengolahan nugget kelinci berpengaruh nyata terhadap peningkatan kadar karbohidrat. Tepung sukun merupakan bahan pangan yang kaya akan kandungan karbohidrat kompleks dengan kategori nilai glikemix index (GI) rendah (Shabella, 2012). Penambahan kurma dan cokelat pada egg roll diharapkan mampu meningkatkan nilai indeks glikemik produk sehingga dapat menyediakan energi secara cepat bagi atlet endurance (Burke, et al., 2004). 
Menurut Hafidha (2017) perhitungan harga (cost) yang dilakukan diketahui tidak berbeda jauh dengan produk egg roll yang berada di pasaran. Snack dengan nilai GI yang sedang dan tinggi lebih diutamakan daripada karbohidrat dengan nilai GI rendah. Karbohidrat berperan dalam menjaga kadar glukosa darah dan kecepatan metabolisme karbohidrat dalam tubuh sehingga dapat mengurangi terjadinya kelelahan pada atlet endurance (Universitas Esa Unggul, 2014). Pernyataan ini didukung oleh hasil penelitian Patel, et al. (2015) bahwasanya konsumsi cokelat pada atlet mampu meningkatkan $\mathrm{VO}_{2} \max$ hingga $6 \%$ daripada sebelum mengonsumsi. Dark chocolate merupakan salah satu jenis bahan makanan dengan kandungan antioksidan (flavonoid) paling tinggi diantara berbagai jenis cokelat, buah-buahan maupun biji-bijian yaitu 13,120/100 gram cokelat (Sudibyo, 2012). Pada atlet dengan jenis olahraga endurance terjadi peningkatan produksi radikal bebas dalam otot skeletal sehingga suplementasi antioksidan dalam jumlah tertentu dapat membantu melindungi otot dari kerusakan yang disebabkan oleh produksi radikal bebas (Scott, KP, et al., 2014).

Pengembangan produk makanan (snack) berbasis tepung sukun merupakan salah satu langkah efektif dalam mendukung program diversifikasi pangan lokal sebagai upaya peningkatan prestasi olahraga melalui perbaikan gizi atlet. Dengan demikian, penambahan tepung sukun, kurma dan cokelat merupakan langkah tepat dalam memberikan alternatif pilihan snack yang sesuai dengan kebutuhan atlet endurance.

\section{KESIMPULAN DAN SARAN}

Berdasarkan uji daya terima yang dilakukan terhadap karakteristik warna, aroma, tekstur dan rasa dapat diketahui bahwasanya tidak terdapat perbedaan daya terima pada formula egg roll dengan penambahan tepung sukun, pisang hijau, kurma dan cokelat. Formula egg roll dengan daya terima terbaik dan kandungan karbohidrat tertinggi dimiliki oleh F1 (tepung sukun $150 \mathrm{~g}$, kurma $150 \mathrm{~g}$ dan cokelat $500 \mathrm{~g}$ ). Nilai karbohidrat pada egg roll $\mathrm{F} 1$ dapat berkontribusi 11,2\% dalam menyumbangkan kebutuhan karbohidrat harian atlet.

Produk egg roll dengan penambahan tepung sukun, kurma dan cokelat (F1) sebaiknya dikonsumsi sesuai takaran saji (125 g/12 batang egg roll) saat sebelum pertandingan/latihan (1-2 jam sebelumnya) sedangkan saat pemulihan (recovery) dapat dikonsumsi setengah atau tiga perempat takaran saji (60-95 g/6-8 batang egg roll).

\section{DAFTAR PUSTAKA}

Almatsier, S. (2004). Penuntun diet. Jakarta: PT Gramedia Pustaka Utama.

Badan Litbang Pertanian. (2015). Tepung sukun mutu premium. Diakses dari http://www.litbang. pertanian.go.id/berita/one/2429/.

Burke, L.M., Kiens, B., \&Ivy, J.L. (2004). Carbohydrates and fat for training and recovery. Journal of Sport Nutritions Sciences, 22, 15-30.

Dayang, J.F., Reuben, C.R., \& Raji, F. (2014). Nutritional, socioeconomic and health benefits if dates. International Journal of Food and Nutritional Sicence, 3(6), 63-73. Diakses dari International Journal of Food and Nutritional Sciences.

Dietetian of Canada. (2016). Nutrition and athletic performance. Canada: Academy of Nutrition and Dietetics and the American College of Sport Medicine.

Driskell, J \& Wolinsky, I. (2011). Second edition nutritional assesment of athlete. Mofwatt, R.J., Tomatis, V.B., Harris, D.A., \& Deetz, A.M: Estimation of Food and Nutrient Intakes of Athlete (1-44). Taylor and Franciss Group, America: CRC Press.

Edahwati, L., Kalimatus, S \& Dian, N. (2010). Kajian penambahan natrium pyrophosfat untuk mencegah browning pada pembuatan tepung sukun. Journal Rekapangan, 4(1) 2-4. Diakses dari www.ejournal.upnjatim.ac.id.

Fadhillah, A.N. (2015). Eksperimen pembuatan egg roll menggunakan bahan komposit tepung koro benguk (mucuna pruriens l) Semarang. Diakses dari http://lib.unnes. ac.id/20300/1/5401409192-S.pdf.

Hendri, Marlina, \& Liferdi. (2010). Diversifikasi pangan dan gizi dengan alpukat, pisang, dan 
sukun. Prosiding Seminar Nasional Program dan Strategi Pengembangan Buah Nusantara. Balitbang: Solok.

Kementerian Kesehatan RI. (2014). Pedoman gizi olahraga prestasi. Jakarta, Indonesia: Kemenkes RI.

Kementerian Perdagangan RI. (2013). Laporan akhir analisis dinamika konsumsi pangan masyarakat indonesia. Jakarta: Kementerian Perdagangan RI.

Kementerian Pertanian RI. (2014). Outlook komoditi kakao. Jakarta: Pusat Data dan Sistem Informasi Pertanian Sekretariat Jenderal Kementerian Pertanian.

Kementerian Pertanian RI. (2015). Statistik produksi holtikultura tahun 2014. Jakarta: Direktorat Jenderal Holtikultura.

Hafidha, K. (2017). Pengaruh penambahan tepung sukun (artocarpus communis), pisang hijau (musa paradisiaca l.), kurma (phoenix dactylifera), dan cokelat (theobroma cacao l.) terhadap daya terima, nilai gizi dan nilai ekonomi egg roll sebagai alternatif snack pada atlet endurance. (Skripsi yang tidak dipublikasikan)

Mustamin., Kunaepah, U \& Ayu,S.D. (2010). Tingkat pengetahuan gizi, asupan dan ostatus gizi atlet di pusdiklat Olahraga pelajar Sudiang Kota Makassar. Media Gizi Pangan, 9 (1), $47-$ 51. Diakses dari Jurnal Media Gizi Pangan.

Partogi, R., Obin, R \& Nani, D. (2012). Pengaruh penggunaan persentase tepung buah sukun (artocarpus communis) terhadap komposisi kimia naget kelinci. E-Jurnal Mahasiswa Universitas Padjajaran, 1(1). Tersedia di www. jurnal.unpad.ac.id.

Palupi, N.S., Zakaria, F.R., \& Prangdimurti, E. (2007). Pengaruh pengolahan terhadap nilai gizi pangan. Bogor: Departemen Ilmu \& Teknologi Pangan IPB.

Patel, R.K., Brouner,J \& Spendiff, O. (2015). Dark Chocolate supplementation reduces the oxygen cost of moderate intensity cycling. Journal of the International Society of Sport Nutrition, 12(47), 2-8. doi: 10.1186/s12970-015-0106-7.

Persatuan Ahli Gizi Indonesia (PERSAGI). (2008). Tabel komposisi pangan Indonesia. Jakarta: PT Elex Media Komputindo Kompas Gramedia.

Pradewi, S. (2013). Perbedaan kualitas indrawi egg roll dari tepung suweg dengan penambahan daun katuk yang berbeda. Semarang. Diakses dari http://ib.unnes.ac.id/19135/1/5401408064. pdf.

Shabella, R. (2012). Terapi daun sukun dahsyatnya khasiat daun sukun untuk menumpas penyakit. Klaten: Cable Book.

Scoot, K.P \& Kurt, J.S. (2014). Endurance exercise and antioxidant suplementation: sense or nonsense-Part 2. Sport Science Exchange, 27 (138), 1-4. Tersedia di www.gssiweb.org.

Sukandar, Muawanah, A., Amelia E.R \& Basalamah, W. (2014). Karakteristik cookies berbahan dasar tepung sukun (artocarpus communis) bagi anak penderita autis. Valensi, 4(1), 13-19. Tersedia di Journal UIN Jakarta.

Sudibyo, A. (2012). Peran cokelat sebagai produk pangan derivat kakao yang menyehatkan. Jurnal Riset Industri, 4(1), 23-40. Tersedia di www. kementrian.go.id.

Tan, T.C., Kanyarat, K \& Azhar, M.E. (2012). Evaluation of functional properties of egg as ingredient in angel food cake. International Food Research Journal, 19(1), 303-308. Tersedia di www.ifrj.upm.edu.my.

Universitas Esa Unggul. (2014). Gizi olahraga (karbohidrat dan olahraga). Jakarta: Jurusan Gizi Fakultas Ilmu Kesehatan.

Widowati, S. \& Djoko S. Damayanti. (2001). Menggali sumber daya pangan lokal dan peran tekhnologi pangan dalam rangka ketahanan pangan nasional. Jakarta: Puslitbang Bulog.

Winarno, F.G. (2004). Kimia pangan dan gizi. Jakarta: PT Gramedia Pustaka Utama. 